\title{
Environmental Water Chemistry and Dissolved Radon Concentration in a Thermal Spring
}

\author{
S. Mohammad Mirhosseini* \\ Department of Geology, Bandar Abbas Branch, Islamic Azad University, Bandar Abbas, Iran
}

Received: 10 October 2014

Accepted: 1 November 2015

\begin{abstract}
Gano thermal spring is a karst spring located in the Zagros zone in southern Iran. Samples were collected in different seasons from this spring water. In addition to physicochemical factors, major and minor ions and dissolved radon concentration were measured at the sampling site using a RAD7 detector. The annual average temperature and electrical conductivity (EC) of Gano water spring is $41.2^{\circ} \mathrm{C}$ and $17,417.5 \mu \mathrm{s} / \mathrm{cm}$. The $\mathrm{pH}$ is in the neutral range and average TDS is $10,442.5 \mathrm{mg} / \mathrm{l}$. The water type is Na-Cl. High Concentrations of $\mathrm{Na}, \mathrm{Cl}$, and $\mathrm{SO}_{4}$ ions probably result from the Hormoz Series salt domes and the dissolution of halite, gypsum, and anhydrite. The $\mathrm{Ca} / \mathrm{Mg}$ ratio in spring water indicates that the reservoir rocks are dolomitic limestone. Concentrations of elements such as $\mathrm{Ag}, \mathrm{Hg}, \mathrm{Cd}, \mathrm{Sn}, \mathrm{Pb}, \mathrm{Cr}, \mathrm{Co}$, and $\mathrm{Bi}$ in Gano water varies from less than 0.5 to $1 \mu \mathrm{g} / \mathrm{l}$. The mean concentration of ${ }^{222} \mathrm{Rn}$ in Gano water is $29.2 \mathrm{kBq} / \mathrm{m}^{3}$, so Gano is not a radon mineral spring. Mean annual effective ${ }^{222} \mathrm{Rn}$ doses for inhalation from the waters of Gano spring was computed to be $0.002 \mu \mathrm{Svy}^{-1}$, which is less than the reference level recommended by WHO.
\end{abstract}

Keywords: water chemistry, Gano thermal spring, salt diapir, radon

\section{Introduction}

Several studies have been done on the chemistry of thermal and hot springs around the world. Some of the purposes of these studies are tourism and environmental studies, determination of resources, monitoring the sources of water, exploring geothermal resources, tectonic and geostructural analysis, exploration of minerals and volcanic activities, etc. [1-6]. Furthermore, studying dissolved gasses and dissolved radioactive ions in groundwater such as $\mathrm{Rn}, \mathrm{U}$, and $\mathrm{Th}$ has received attention in many hydrochemical studies of thermal springs [7-17].

Radon is a natural radioactive gas without odor, color, or taste. It cannot be detected without special equipment.

*e-mail: Mirhoseini.sm@gmail.com
Radon naturally results from the radioactive decay of uranium and thorium. Uranium and thorium are natural radioactive materials found in varying amounts in all rocks, soils, and sediments. They occur everywhere on earth, especially in rocky and mountainous areas. Among various isotopes of radon, ${ }^{222} \mathrm{Rn}$ is more important and receives more attention in environmental studies. This isotope has a half life of 3.8 days, and thus has enough time to remain in the air and water of the human environment and causes threats to human health such as lung cancer [18]. The short-lived decay products of radon are responsible for most inhalation hazards.

The use of thermal and mineral spring waters in hydrotherapy and Balneutherapy has a very long history. This is one of important reasons for studying the hydrochemistry of such springs. Balneutherapy is a traditional and experimental treatment method that 
includes immersing the body of the patient in the warm or cold mineral water in order to treat some diseases [19, 20]. This type of treatment is mainly used for treating skin diseases, perhaps because of the prevalence of such diseases in developing countries and its cheaper price compared to dermatological methods.

More than 469 thermal and mineral springs have been identified in Persia [21]. In Hormozgan Province along the Persian Gulf, because of its active tectonic and geological features such as successive anticlines and synclines of the Zagros folded zone and consisting of several salt domes, there are numerous thermal springs, and more than 20 of them are used in the treatment of disease.

The most important thermal spring in Hormozgan is Gano Spring. Despite the long history of Gano spring in Balneutherapy, there has been no comprehensive study of its water chemistry. Because of the determinative role of spring hydrochemistry on the type of its therapeutic use and due to the exploration of some radioactive anomalies in salt domes of Hormozgan in recent years, concerns about thorium, uranium, and radon concentrations in such springs have only increased.

\section{Experimental Procedure}

\section{Description of Study Area}

Gano Spring is a karst spring located $35 \mathrm{~km}$ north of Bandar Abbas City on the eastern edge of double plunges Gano anticline in Hormozgan Provice in the Zagros folded zone in southern Iran. The major geological outcrop units in this area from old to new include [22] (Fig. 1):

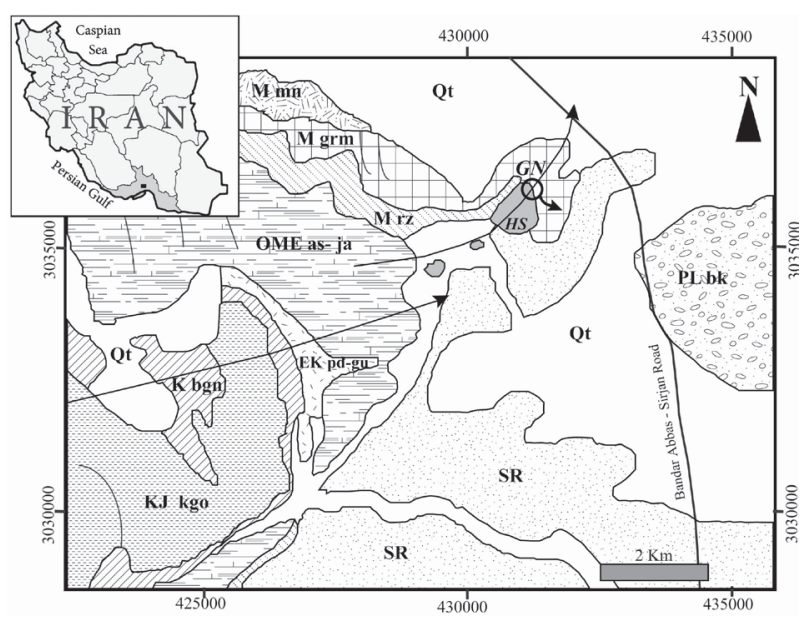

Fig. 1. Geological map of the eastern part of the Geno anticline [22].

(GN: Gano Spring, HS: Hormoz Series salt diapirs, KJ kgo: Khami Group, K bng: Bangestan Group, EK pd-gu: Pabdeh-Gurpi Formations, OME as-ja: Asmari-Jahrum Formation, M rz: Razak Formation, M mn: Mishan Formation, M grm: Guri member, PL bk: Bakhtiyari Formation, SR: Sub recent deposits, Qt: Alluvium and recent deposits)
Table 1. Mean chemical composition of Gano Spring in different seasons of 2013 (GN1: winter, GN2: spring, GN3: summer, and GN4: autumn).

\begin{tabular}{|c|c|c|c|c|c|c|}
\hline GN & & GN1 & GN2 & GN3 & GN4 & Mean \\
\hline $\mathbf{T}$ & ${ }^{\circ} \mathrm{C}$ & 40.2 & 41.2 & 41.4 & 42.1 & 41.22 \\
\hline $\mathbf{E C}$ & $\begin{array}{c}\mu \mathrm{s} / \\
\mathrm{cm}\end{array}$ & 18840 & 15060 & 14120 & 21650 & 17417.5 \\
\hline $\mathbf{T . D . S}$ & $\mathrm{mg} / \mathrm{L}$ & 10100 & 9300 & 8770 & 13600 & 10442.5 \\
\hline $\mathbf{p H}$ & & 7.6 & 6.71 & 7.01 & 7.27 & 7.14 \\
\hline $\mathbf{C a}^{2+}$ & $\mathrm{mg} / \mathrm{L}$ & 418 & 374 & 393 & 311 & 374 \\
\hline $\mathbf{M g}^{2+}$ & $\mathrm{mg} / \mathrm{L}$ & 104 & 92.6 & 92.7 & 84.2 & 93.37 \\
\hline $\mathbf{N a}^{+}$ & $\mathrm{mg} / \mathrm{L}$ & 3090 & 2840 & 2750 & 2890 & 2892.5 \\
\hline $\mathbf{K}^{+}$ & $\mathrm{mg} / \mathrm{L}$ & 111 & 160 & 91.2 & 79.7 & 110.47 \\
\hline $\mathbf{S r}^{2+}$ & $\mathrm{mg} / \mathrm{L}$ & 15.8 & 16.2 & 13.6 & 20.2 & 16.45 \\
\hline $\mathbf{H C O}_{3}^{--}$ & $\mathrm{mg} / \mathrm{L}$ & 26 & 219 & 214 & 249 & 177 \\
\hline $\mathbf{C O}_{3}{ }^{2-}$ & $\mathrm{mg} / \mathrm{L}$ & 5 & 7 & 0.225 & 0.225 & 3.1125 \\
\hline $\mathbf{S O}_{4}{ }^{2-}$ & $\mathrm{mg} / \mathrm{L}$ & 687 & 653 & 908 & 713 & 740.25 \\
\hline $\mathbf{C l}^{-}$ & $\mathrm{mg} / \mathrm{L}$ & 5105 & 4609 & 4538 & 5318 & 4892.5 \\
\hline $\mathbf{S}^{2}$ & $\mathrm{mg} / \mathrm{L}$ & 322 & 340 & 315 & 1220 & 549.25 \\
\hline $\mathbf{P}^{2}$ & $\mathrm{mg} / \mathrm{L}$ & 0.07 & 0.03 & 0.3 & 0.04 & 0.11 \\
\hline $\mathbf{F e}^{2}$ & $\mathrm{mg} / \mathrm{L}$ & 0.0075 & 0.05 & 0.02 & 0.0075 & 0.0116 \\
\hline $\mathbf{B}^{2}$ & $\mu \mathrm{g} / \mathrm{L}$ & 1780 & 2740 & 1780 & 3040 & 2335 \\
\hline $\mathbf{S i}^{2}$ & $\mu \mathrm{g} / \mathrm{L}$ & 7120 & 7050 & 11700 & 6810 & 8170 \\
\hline $\mathbf{L i}^{2}$ & $\mu \mathrm{g} / \mathrm{L}$ & 1700 & 1990 & 1650 & 1420 & 1690 \\
\hline & & & & & & \\
\hline
\end{tabular}

- Khami Group: limestone, shale, dolomite limestone, and anhydrite;

- Bangestan Group: shale and limestone of Cretaceous age (Upper Jurassic);

- Pabdeh-Gurpi Formations: Calcareous Shale and gray marl;

- Asmari-Jahrum Formation: limestone and dolomite (Eocene-Oligocene);

- Razak Formation: sandstone (Miocene), marl sandy limestone;

- Mishan formation: marl and limestone (Guri member, Miocene);

- Aghajari formation: Marle, sandstone (Pliocene);

- Bakhtiyari formation: coarse conglomerate (Pliocene).

There is also an outcrop of Hormoz Series salt diapirs in this area. Chloride minerals, halite $(\mathrm{NaCl})$, and sylvite $(\mathrm{KCl})$, plus gypsum and anhydrite (calcium sulfates), are the most abundant constituents of the Hormoz Series salt diapirs whose dissolving increases the total amount of solids in local groundwater [23].

The reign's climate is warm and dry and the annual rainfall is about $170 \mathrm{~mm}$. The discharge average of Gano spring is $140-150 \mathrm{~L} / \mathrm{s}$, and its height from sea level is $520 \mathrm{~m}$. 

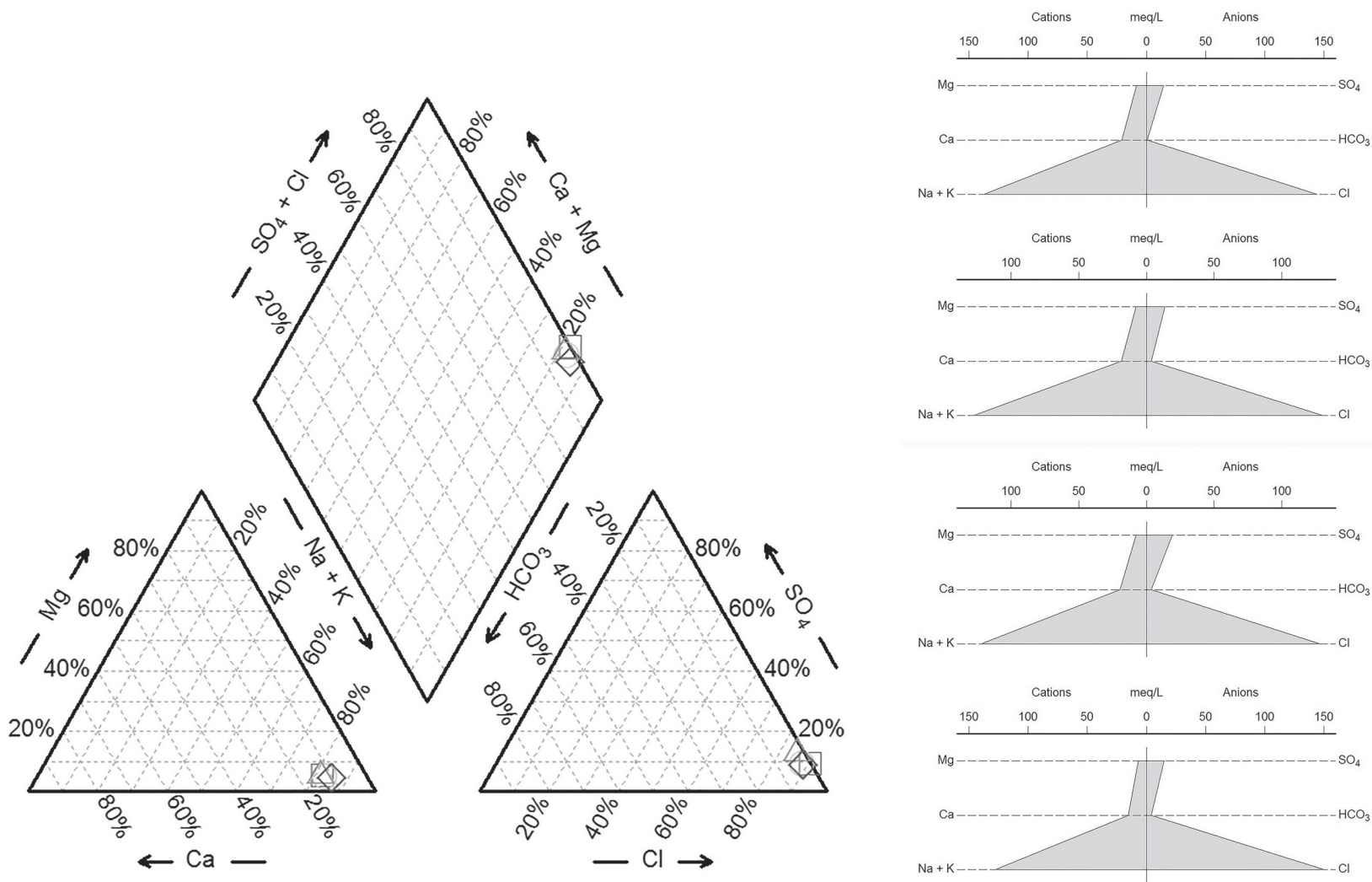

Fig. 2. Stiff diagrams of Gano water samples and the position of samples in a Piper diagram.

\section{Collection and Analysis of Samples}

Sampling was done through four steps in different seasons. Physicochemical parameters such as EC, $\mathrm{pH}$, and temperature were measured at the sampling site using a portable multimeter. The major cations, some minor and rare metal and non-metal elements (such as As, Ag, Bi, $\mathrm{Cd}, \mathrm{Co}, \mathrm{Cr}, \mathrm{Hg}, \mathrm{Cu}, \mathrm{Pb}, \mathrm{Zn}, \mathrm{Mn}, \mathrm{Se}, \mathrm{U}$, etc.), and minor

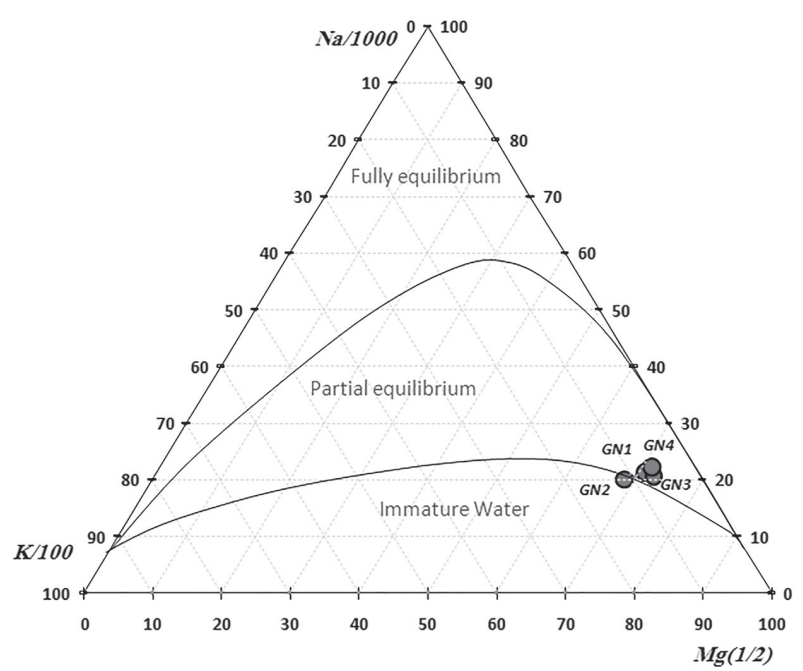

Fig. 3. Position of Gano water samples in a Giggenbach Na-K$\mathrm{Mg}$ triangular diagram. anions were measured using ICP-MS, ICP-OES, and the major anions ( $\mathrm{SO} 4, \mathrm{Cl}, \mathrm{HCO}_{3}$, and $\mathrm{CO}_{3}$ ) were measured using titration, atomic absorption, and flame photometry. Furthermore, the concentration of cancer-causing radon gas was measured in each sampling stage using a RAD7 radon detector.

\section{Resault and Discussion}

The average amounts of major anions, cations and other physicochemical parameters of Gano Spring are shown in Table 1. The annual average temperature of the spring is $41.22^{\circ} \mathrm{C}$, average $\mathrm{pH}$ is in neutral range, and average $\mathrm{EC}$ is $17417.5 \mu \mathrm{s} / \mathrm{cm}$.

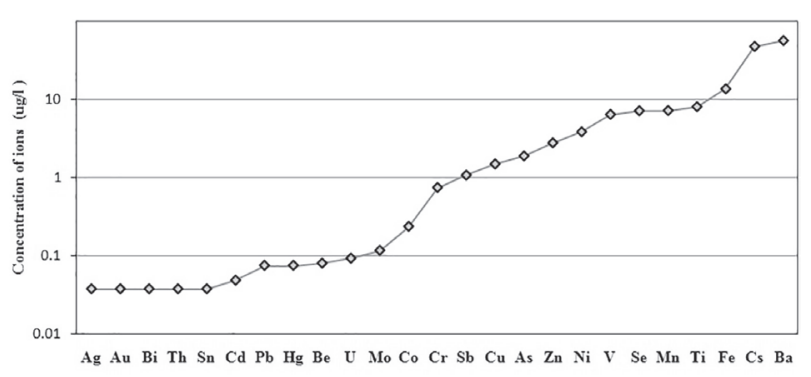

Fig. 4. Average concentrations of some minor elements and heavy metals in Gano Thermal Spring. 
Table 2. Comparison of ${ }^{222} \mathrm{Rn}$ concentrations observed in this study with the results of other studies.

\begin{tabular}{|c|c|c|}
\hline Study & ${ }^{222} \mathrm{Rn}$ activity $\left(\mathrm{Bq}^{-1}\right)$ & Country \\
\hline This Study & $9.87-46.3$ & Iran, Gano \\
\hline$[21]$ & $7.4-253$ & Iran, Bastak \\
\hline$[14]$ & $9.7-139.8$ & Iran, Sareen \\
\hline$[12]$ & $145-2,731$ & Iran, Mahallat \\
\hline$[15]$ & 42.5 & Iran, Kerman \\
\hline$[13]$ & $3.18-46.9$ & India \\
\hline$[17]$ & $0.21-5.82$ & Turkey, Yalova \\
\hline$[30]$ & $0.51-8.5$ & Turkey, Izmir \\
\hline$[31]$ & $0.11-0.71$ & Turkey, Amasya \\
\hline$[32]$ & $24.5-648$ & Serbia \\
\hline$[33]$ & $53.4-292.5$ & China \\
\hline$[34]$ & $7.7-506.2$ & Italy \\
\hline$[9]$ & $1-560$ & Venezuela \\
\hline$[35]$ & $1.8-98$ & Hungary \\
\hline$[36]$ & $0.225-130$ & Spain \\
\hline$[37]$ & $4.5-110.8$ & Romania \\
\hline
\end{tabular}

The frequency of major ions in the spring is $\mathrm{Na}>\mathrm{Ca}>$ $\mathrm{Mg}>\mathrm{K}$ and $\mathrm{Cl}>\mathrm{SO}_{4}>\mathrm{HCO}_{3}>\mathrm{CO}_{3}$, and the water type is $\mathrm{Na}-\mathrm{Cl}$ (Fig. 2). High concentrations of $\mathrm{Na}, \mathrm{Cl}$, and $\mathrm{SO}_{4}$ ions and high amounts of TDS and EC of Gano spring water probably results from the effect of the Hormoz Series Salt Domes and dissolving minerals such as halite, gypsum, and anhydrite that have significant effects on the salinity of groundwater and their low qualities in this area.

In karstic springs the ratio of $\mathrm{Ca} / \mathrm{Mg}$ determines the type of reservoir rocks and the high amounts of this ration $(>2.5)$ show the purity of limestone reservoir rocks [24]. The average ratio of $\mathrm{Ca} / \mathrm{Mg}$ in Gano Spring water is 2.39, which indicate that the reservoir rocks are dolomitic limestones. This type of reservoir rock matches the AsmariJahrom formation, which has considerable extension in the Zagros Mountains and in Gano Anticline.

The situation of Gano spring samples in the Giggenbach Na-K-Mg triangular diagram [4] (Fig. 3) shows that these relatively mature waters are in partial equilibrium with its reservoir rocks. The linear relationship between $\mathrm{Cl}^{-}$and $\mathrm{Mg}^{2+}$ ions rejects the mixing of waters that originate from different sources [25]. In Gano Spring, with respect to the weak correlation between $\mathrm{Cl}$ and $\mathrm{Mg}$ ions $(0.016)$, the mixing of deep waters with shallow or surface waters during ascension seems likely.

Results of chemical analysis of Gano water samples also show that concentrations of some minor elements and heavy metals, despite the high TDS of water, is not so high. Average concentrations of $\mathrm{Ag}, \mathrm{Au}, \mathrm{Bi}, \mathrm{Th}, \mathrm{Cd}$, $\mathrm{Sn}, \mathrm{Pb}, \mathrm{Hg}, \mathrm{U}$, are $\mathrm{Be}$ are less than $0.5 \mu \mathrm{g} / \mathrm{l}$, average concentrations of $\mathrm{Mo}, \mathrm{Co}$, and $\mathrm{Cr}$ vary between $0.1-1 \mu \mathrm{g} / \mathrm{l}$, and average concentrations of ions such as $\mathrm{Cu}, \mathrm{As}, \mathrm{Ni}, \mathrm{Se}$, and $\mathrm{Zn}$ are higher than $1 \mu \mathrm{g} / \mathrm{l}$ (Fig. 4). Low concentrations of such elements may be due to the neutral and alkaline $\mathrm{pH}$ of the spring water and also their low concentrations in carbonate reservoir rocks.

Measurements of dissolved radon concentrations of Gano water spring at the sampling site show that ${ }^{222} \mathrm{Rn}$ concentrations have great changes through different times (CV: 0.51). Mean concentrations of ${ }^{222} \mathrm{Rn}$ in winter, spring, summer, and autumn of 2013 were $29.18,31.47,9.87$, and $46.3 \mathrm{kBq} / \mathrm{m}^{3}$, respectively.

Differences of recorded concentrations of ${ }^{222} \mathrm{Rn}$ at different times is common in those areas with active tectonics in which bedrock motion has a great effect on the release and rise of generated radon. So, changes in radon concentrations can be used to predict earthquakes [15, 16, 26].

The Zagros folded region is tectonically one of the most active parts of Iran. Although most of the earthquakes in the Zagros are not that large, their number is considerable. Concentrations of radon in curative mineral waters vary widely. For example, the minimum admissible norms of radon concentration for curative mineral waters in Italy and Poland are 48 and $74 \mathrm{~Bq} / 1$, and in France, Czech, and Germany they are $370,1,192$, and $6,885 \mathrm{~Bq} / 1$, respectively [27]. The annual average radon concentration in Gano Spring is $29.2 \mathrm{kBq} / \mathrm{m}^{3}$, so it is not classified as radon mineral springs.

However, Gano water is not potable due to its very poor quality, and it is consumed only for the treatment of certain diseases according to old beliefs and traditions; mean ${ }^{222} \mathrm{Rn}$ concentration of this spring is higher than the recommended EPA standard of $3.11 \mathrm{~Bq} / 1$ [28], which is lower than the WHO standard of $100 \mathrm{~Bq} / 1$ [29] for potable water.

The range of radon concentration in Gano is compared to those of other regions' springs around the world in Table 2 [9, 12-15, 17, 21, 30-37]. The average concentration of radon in this spring was more than springs in areas such as I'zmir and Amasya in Turkey, and less than springs in China and Serbia and Mahallat hot spring in Iran.

As mentioned previously, Gano is one of the famous centers of hydrotherapy and balneutherapy in southern Iran. Therefore, in order to evaluate the radiological risk from exposure, the annual mean effective doses from inhalation of ${ }^{222} \mathrm{Rn}$ in Gano water were estimated. The dose contribution arising from the release of ${ }^{222} \mathrm{Rn}$ in water to the air is calculated using the relation [38]:

$$
\mathrm{D}_{\text {inh }}=\mathrm{C}_{\mathrm{Rn}} \cdot \mathrm{R}_{\mathrm{w}} \cdot \mathrm{F} \cdot \mathrm{T} \cdot \mathrm{D}_{\mathrm{f}}
$$

...where $\mathrm{C}_{\mathrm{Rn}}$ (in $\mathrm{Bqm}^{-3}$ ) is the radon concentration in water, $R_{w}$ is the ratio of radon in air to the radon in water $\left(10^{-4}\right), \mathrm{T}$ is the average indoor occupancy time per person (twice a week, each time for two hours: $192 \mathrm{hy}^{-1}$ ), F is the equilibrium factor between radon and its progenies (0.4), and $\mathrm{D}_{\mathrm{f}}$ is a dose conversion factor $\left(9 \mathrm{nSv} \mathrm{h}{ }^{-1} \mathrm{~Bq}^{-1} \mathrm{~m}^{3}\right)$ [43]. Mean annual effective doses for inhalation from Gano waters was computed to be $0.002 \mu \mathrm{Svy}^{-1}$, which is much 
less than the reference level of $100 \mu \mathrm{Svy}^{-1}$ recommended by WHO [29]. Thus it can be concluded that radon poses no threat to the people who use the spa waters for medical purposes.

\section{Conclusion}

The presence of several salt diapirs in the folded Zagros zone in southern Iran and the dissolution of their soluble minerals, mainly through joints and fractures, increases the total amount of dissolved solids in local groundwater.

Due to the effects of the Hormoz series outcrops of salt domes, Gano spring water is so saline and has high TDS and EC. The type of water is $\mathrm{Na}-\mathrm{Cl}$, which has special applications in hydrotherapy and balneutherapy. This type of water stimulates different activities of the body, relives swelling, and if it is combined with gas has soothing effects, makes breathing easier, and stimulates the pancreas and gastrointestinal tract [39].

$\mathrm{The} \mathrm{Ca} / \mathrm{Mg}$ ratio in Gano spring water indicates that the spring reservoir rocks are dolomitic limestones. Because of the reservoir lithology and water's neutral $\mathrm{pH}$, the measured concentrations of minor elements and heavy metals such as $\mathrm{Cr}, \mathrm{Co}, \mathrm{Ag}, \mathrm{Hg}, \mathrm{Cd}$, and $\mathrm{Pb}$ in water are very low, and because those studied springs are not used as sources of potable water, there is no worry in this regard. However, due to the toxicity of most of these elements, using such waters in balneutherapy in ways such as drinking, fumigation, and injection is not advised.

The results of dissolved ${ }^{222} \mathrm{Rn}$ measurements in Gano Spring water show that its average concentration is less than the amount recommended by WHO and higher than the recommended EPA standards of $148 \mathrm{kBq} / \mathrm{m}^{3}$ and a transmission coefficient of radon from water to air of $10000 / 1$. Therefore, according to the ${ }^{222} \mathrm{Rn}$ measurements in this study and the value of calculated $\mathrm{D}_{\text {inh }}$ and due to the proper ventilation in Gano Spa, client health is not at risk.

\section{References}

1. CARON M.E., STEPHEN E., GRASBY M., RYAN C. Spring water trace element geochemistry: A tool for resource assessment and reconnaissance mineral exploration. Appl Geochem. 23 (12), 3561, 2008.

2. GUSTAVO N. S. A $21^{\text {st }}$-Century Approach to Health Tourism Spas: The Case of Portugal. J Hosp Manage Tourism. 17 (1), 127, 2010.

3. NEGARESTANI A., NAMVARAN M., SHAHPASANDZADEH M., FATEMI S.J., ALAVI S.A., HASHEMI S.M., MOKHTARI M. Design and investigation of a continuous radon monitoring network for earthquake precursory process in Great Tehran. J Radioanal Nucl Chem. 300 (2), 757, 2014.

4. GIGENBACH W.F., GLOVER R.B. Tectonic regime and major process governing the chemistry of water and gas discharges from the Rotorua geothermal field, new Zwland. Geothermics. 21 (1/2), 121, 1992.

5. GIGGENBACH W.F. Isotopic shifts in waters from geothermal and volcanic systems along convergent plate boundaries and their origin. Earth Planet Sc Lett. 113, 495, 1992.

6. GUO Q., WANG Y. Geochemistry of hot springs in the Tengchong hydrothermal areas, Southwestern China. J Volcanol Geotherm Res. 215, 61, 2012.

7. EREES F.S., AYTAS S., SAC M.M., YENER G., SALK M. Radon concentrations in thermal waters related to seismic events along faults in the Denizli Basin, Western Turkey. Radiat Meas. 42, 80, 2005.

8. GHADIMI F., MIRZAEI M., GHOMI M., ARAGHI M. Multivariate statistical analyzing of chemical parameters of thermal and non-thermal springs of Mahalat area in Iran. J Geope. 3 (1), 57, 2013.

9. HORVATH A.D., BOHUS L. O., URBANI F., MARX G., PIROTH A., GREAVES E.D. Radon concentrations in hot spring waters in northern Venezuela. J Environ Radioact. 47, 127, 2000.

10. PRZYLIBSKI T.A., KOZŁOWSKA B., DORDA J., KIELCZAWA B. ${ }^{222} \mathrm{Ra}$ and ${ }^{226} \mathrm{Ra}$ concentrations in mineralized groundwaters of Gorzano'w (Kłodzko Basin, Sudeten Mountains, SW Poland). J Radioanal Nucl Chem. 253 (1), 11, 2002.

11. EREES F.S., YENER G., SALK M., ÖZBAL Ö. Measurements of radon content in soil gas and in the thermal waters in Western Turkey. Radiat Meas. 41, 354, 2006.

12. BEITOLLAHI M., GHIASSI-NEJAD M., ESMAELI A., DUNKER R. Radiological studies in the hot spring region of Mahallat, Central Iran. Radiat Prot Dosim. 123 (4), 505, 2007.

13. CHAUDHURI H., NISITH K.D., BHANDARI R.K., SEN P., SINH B. Radon activity measurements around Bakreswar thermal springs. Radiat Meas. 45, 143, 2010.

14. KARIMDOUST SH., ARDEBILI L. The Environmental Impact of Radon Emitted from Hot Spring of Sarein (A Touristic Sity Northwestern Iran. World Appl Sci J. 10 (8), 930, 2010.

15. MONTAZERI H., ABBASNEJAD A., NEGARESTANI A. Continuous radon monitoring in the Jowshan hot spring as an earthquake precursor, SE Iran. Geochem J. 45, 463, 2011.

16. NAMVARAN M., NEGARESTANI A. Measuring the radon concentration and investigating the mechanism of decline prior an earthquake (Jooshan, SE of Iran). J Radioanal Nucl Chem. 298 (1), 1, 2012.

17. TABAR E., YAKUT H. Radon measurements in water samples from the thermal springs of Yalova basin, Turkey. J Radioanal Nucl Chem. 299 (1), 311, 2014.

18. FINN L.S. Detection, measurement and gravitational radiation. Phys Rev. 46 (12), 5236, 1992.

19. ROTH H. B., BHOWMIK K.R., PARISH L.C., WITKOWSKI J.A. Balneology, mineral water, and spas in historical perspective. Clin Dermatol. 6, 551, 1996.

20. MILLIKAN L.E. Complementary medicine in dermatology. Clin Dermatol. 5, 602, 2002.

21. MIRHOSSEINI S.M., NEGARESTANI A., MOATTAR F., KARBASSI A.R. Water chemistry and radon concentrations of thermal springs in Bastak area, south of Persia. J Radioanal Nucl Chem. 304, 1085, 2015.

22. Iranian Oil Operation Company (IOOC), Geological and Exporation Division. geological map of Bandar Abbas Sheet. 1988.

23. KARIMI H., MOORE F. The source and heating mechanism for the Ahram, Mirahmad and Garu thermal springs, Zagros Mountains, Iran. Geothermics. 37, 84, 2008.

24. KARAMI GH. Assessing The Heterogeneity And Flow System Types In Karstic Aquifers using Pumping Test Data. Ph.D. Thesis, University Of Newcastle, Newcastle, Upon Tyne, 180, 2002. 
25. MANZOOR A., WAHEED A., NIAZ A., MUHAMMAD A.T. Assessment of reservoir temperatures of thermal springs of the northern areas of pakestan by chemical and isotope geothermometry, Geothermics. 31, 613, 2002.

26. GHOSH D., DEB A., SENGUPTA R. Anomalous radon emission as precursor of earthquake. Journal of Applied Geophysics. 69 (2), 67, 2009.

27. PONIKOWSKA I., ADAMCZYK P., KHAI V. The Clinical Principles of Balneology \& Physical Medicine. Balneology J - winter 2003. Adapted from: Ponikowska I. 2002. Polska droga rozwoju lecznictwa uzdrowiskowego. Balneologia Polska. 44, 105, 2003.

28. EPA. Office of Water - 4607M. Report to Congress: Radon in Drinking Water Regulations. 815-R-12-002. 2012.

29. WHO. Guidelines for Drinking-Water Quality, second addendum. Vol. 1, Recommendations. $3^{\text {rd }}$ ed. ISBN 978924 154760 4. World Health Organization, Geneva, 2008.

30. BOLCA M., SAC M.M., ALTINBAS U., CAMGO Z.B. Chemical and radioactivity effects of geothermal springs on environmental pollution in Seferihisar region in western Turkey. Asian J Chem 19 (3), 2265, 2007.

31. ONER F., YIGITOGLU I., YALIM H.A. Measurements of radon concentrations in spa waters in Amasya, Turkey. Radiat Prot Dosim. 157 (2), 221, 2013.

32. NIKOLOV J., TODOROVIC N., PETROVIC PANTIC T., FORKAPIC S., MRDJA D., BIKIT I., KRMAR M., VESKOVIC M. Exposure to radon in the radon spa Niska Banja, Serbia. Radiat Meas. 47, 443, 2012.
33. SONG G., WANG X., CHEN D., CHEN Y. Contribution of ${ }^{222} \mathrm{Rn}$ - bearing water to indoor radon and indoor air quality assessment in hot spring hotels of Guangdong, China. J Environ Radioact. 102 (4), 400, 2011.

34. BERTOLO A., BIGLIOTTO C. Radon concentration in waters of geothermal Euganean basin-Veneto, Italy. Radiat Prot Dosim. 111 (4), 355, 2004.

35. EROSS A., MADL-SZONYI J., SURBECK H., HORVATH A., GOLDSCHEIDER N., CSOMA A.E. Radionuclides as natural tracers for the char-acterization of fluids in regional discharge areas, Buda Thermal Karst, Hungary. J Hydrol. 426-427, 124, 2012.

36. DUENAS C., FERNANDEZ M.C., ENRAQUEZ C., CARRETERO J., LIGER E. Natural radioactivity levels in Andalusian spas. Water Res. 32 (8), 2271, 1998.

37. ROBA C.A., NITA D., COSMA C., CODREA V., OLAH $\mathrm{S}$. Correla-tions between radium and radon occurrence and hydrogeochem-ical features for various geothermal aquifers in Northwestern Romania. Geothermics. 42, 32, 2012.

38. United Nations Scientific Committee on the Effects of Atomic Radiation (UNSCEAR). Sources and effects of ionizing radiation. UNSCEAR 2000 Report. United Nations Publication. 2000.

39. KATZ U., SHOENFELD Y., ZAKIN V., SHERER Y., SUKENIK S. Scientific Evidence of the Therapeutic Effects of Dead Sea Treatments: A Systematic Review. Semin Arthritis Rheu. 42, 186, 2012. 